\section{Pensar a internet}

\section{RESUMO}

Este artigo faz uma reflexão crítica sobre a internet. Para 0 autor é preciso pensar a internet conforme as dimensões da técnica, da cultura e da sociedade e ainda discutir os três níveis que a revolução da internet se fetua: 0 internauta, 0 indivíduo e o cidadão.

\section{ABSTRACT}

This article is a critical reflection upon the internet. According to its author, we have to think about it in terms of its technical, cultural and social dimensions, without ever forgetting taking the three roles of the subject into account in that revolution: that of the web surfer, that of the individual and that of the citizen.

\section{PALAVRAS-CHAVE/KEY-WORDS \\ - Internet \\ - Novas tecnologias (New technologies) \\ - Subjetividade (Subjectivity)}

Dominique Wolton

Pesquisador CNRS/França
Muitos jovens aCREDitam de bom grado, porque todo mundo diz, que tudo vai mudar com a Internet. Para evitar que eles sejam amanhã uma espécie de "geração perdida", vencida pela técnica, é preciso fazer nascer uma reflexão crítica, "pensar a Internet" dentro da articulação de três dimensões de comunicação: técnica, cultura e sociedade. É por isso que eu gostaria de fazer três reflexões que atingem respectivamente os três níveis em que a "revolução" da Internet se efetua: o internauta, o indivíduo, o cidadão.

\section{O internauta}

Sim à criatividade que emerge depois de duas gerações marcadas pela crise. A aventura começa pela técnica, sua miniaturização e sua potência fenomenal, tornando arcaica a televisão, que foi por muito tempo considerada o auge da modernidade.

Sim também a essa tecnicidade que desenha uma geração com necessidade de tomar seu espaço e marcar seu território.

Sim, enfim, a essas milhões de experiências que, na economia, nos serviços, na educação, no lazer provam que cada nova técnica relança a inovação.

Mas é preciso também lembrar o internauta, para evitar graves desilusões, dos três pontos a seguir.

Em primeiro lugar, que o mais difícil não é a informação, mas a comunicação.

Ora, a Internet não passa de um sistema automatizado de informação; de uma forma ou de outra, são os homens e as coletividades que integram esses fluxos de informações em suas comunicações. A informação é sempre um segmento, e somente a comunicação, com suas prodigiosas ambigüidades, the faz emergir um sentido. Esta é então toda a ambigüidade do tema da economia da informação, aquela que é apresentada ao mesmo tempo como um avanço 
à economia da produção, um novo estágio dentro da história dos sistemas de produção e da origem de uma nova sociedade mais democrática! Não há vínculo direto entre nova economia e nova sociedade. $A$ rede pode ajudar a suprimir "o combustível" da economia capitalista sem ser, ao contrário do que dizem alguns, a fonte de uma nova riqueza. Duas questões precisam ser ainda elucidadas: qual é a produtividade de uma economia de signos? E qual analogia existe entre esta economia do signo e a economia da produção que desde sempre esteve na base da riqueza? Dizer que tudo é informação e troca não é suficiente para criar uma nova economia. Existe, por um lado, a Rede, aceleradora da circulação e da rentabilidade do capital, e por outro lado a Rede, criadora em si de valor e de riqueza. Ao contrário do que é dito, não há ligação direta entre os dois: o problema da criação de valor, portanto, do elo entre informação e produção, que sempre foi o coração da economia, não está de fato ainda regulado.

Depois, não é suficiente que os homens troquem muitas informações para que se compreendam melhor. São os planos culturais e sociais de interpretação das informações que contam, não o volume ou a diversidade dessas informações. O uso não faz a economia do projeto. O tempo ganho no acesso à informação pode ser novamente perdido na dificuldade de interpretar essa informação. Por isso, em algum momento, é preciso também aconselhar o internauta a sair da comunicação mediatizada e se confrontar com a comunicação natural humana e social. Daí a importância dos contatos, da voz, dos olhares, além da troca de signos. Atenção às solidões interativas!

Enfim, a performance mesma dos sistemas de informação obriga o internauta a refletir sobre o estatuto da informação e a diferenciar as lógicas, os valores presentes. Da informação-serviço à informação-notícia, da informação- conhecimento à informação-lazer, não se trata dos mesmos sistemas de referência e de legitimidade. Diz-se que a informação não existe em si; ela é ligada a um conjunto de conhecimentos, a uma construção. As ligações hipertextuais não estabelecem somente relações entre as idéias e os conhecimentos, elas estabelecem, com seus "a priori" e com a rigidez real que as acompanham, uma geografia do conhecimento. Nenhuma topologia é neutra.

\section{O indivíduo}

Sim ao sentimento de liberdade que surge dessa nova aventura da Internet. Para uma geração, é uma possibilidade de emancipação que se abre, e o meio de se distanciar das gerações precedentes que, da informática às telecomunicações e à explosão do audiovisual, davam o sentimento de ter monopolizado o progresso técnico. Aqui a história se refaz, redistribuindo as cartas, transcendendo a rigidez geográfica, rompendo o isolamento e mesmo instituindo novas bases de solidariedade entre os indivíduos, o Norte e o Sul. Tanto um cibercafé como um estágio de Internet são meios de conhecer pessoas. Os homens que trabalham na Rede formam uma comunidade que deixa visível, pouco a pouco, a Internet, a familiarizam e a humanizam. O uso generalizado do teclado constitui uma forma de cultura que atravessa os países, as línguas e as classes sociais. Então, em nome de que desqualificar essa nova aventura individual e coletiva, aberta a todos e por enquanto não-hierárquica e não-acadêmica?

É conveniente lembrar três questões que relativizam esse novo "humanismo".

Em primeiro lugar, não se pode deixar a informação da comunicação ser totalmente absorvida pela economia. O que está em jogo na Internet é saber se restará um espaço qualquer de liberdade individual uma vez que a racionalidade econômica 
a terá arrebatado. O indivíduo não saberá aceitar tornar-se a aposta de um imenso sistema de comércio eletrônico. O que sobrará então da liberdade individual, colocada em risco tanto pela cibercrimi nalidade quanto pelos múltiplos sistemas de viabilidade já estabelecidos? Entre a liberdade, a viabilidade, a comercialização de todas as atividades, a margem de manobra é muito estreita. Sobretudo sem regulação. Daí a importância de um humanismo e das utopias para dar um conteúdo diverso do econômico às informações. Que projeto os homens podem inventar para dar um sentido a esse sistema técnico?

Em seguida, é preciso saber distinguir a informação-valor, que é fator de liberdade individual, da informação-mercadoria que, essa, é padronizada. Da mesma maneira, a qualidade das informações às quais os indivíduos têm acesso deve sempre ser questionada. Não somente em termos de veracidade, mas também em termos da Internet. O grosso das informações acessíveis na Internet não apresenta grande interesse, é preciso ter a honestidade de reconhecê-lo.

Enfim, e isto resulta do ponto precedente, é preciso valorizar o receptor, quer dizer, o usuário final, de cujas expectativas e aderência àquilo que lhe é proposto jamais se está certo. O receptor é o quebra-cabeça da comunicação. É preciso de resto lembrar a existência da desigualdade de conhecimentos, de competências, mas também de interesses. Para alguns, a Internet é uma nova fronteira; para outros, um simples instrumento; para outros ainda, uma obrigação de comunicação suplementar.

Em todo caso, será necessário pensar na mobilidade, refletir em que consiste seu ideal numa sociedade na qual tudo já circula em todos os sentidos, há cinqüenta anos. A obsessão da rapidez, da mobilidade, não cria novas desigualdades? Sobretudo quando se sabe quanto tempo levam os homens para se compreender um pouco melhor...

\section{O cidadão}

Sim à idéia de relançar uma reflexão sobre a democracia e a participação política a partir da Internet. A tela reatualiza esse postulado clássico do modelo democrático segundo o qual aquele que detém a informação tem o poder. Se cada um pode ter acesso a tantas informações, de qualquer lugar, são as hierarquias, a lógica do poder e do segredo que se encontram abaladas.

Tanto melhor se um sistema técnico relança uma utopia política em favor de informações mais diretas, até (simplesmente) a possibilidade de um melhor controle do poder.

Mas se não se quer que o econômico prevaleça ainda sobre o político, é preciso refletir sobre três problemas.

Primeiro, é preciso integrar a Internet ao campo de debates políticos e, conseqüentemente, sair da unanimidade atual que impede toda a reflexão crítica. Tirar a Internet do reino da crença para fazê-la entrar no dos debates onde se opõem diversas maneiras de utilizá-la. A Internet é a única inovação sobre a qual não há debates. Sobre as biotecnologias, os OGM (organismos geneticamente modificados), a energia nuclear, as tecnologias do ser vivo, há confrontos políticos, ideológicos. Sobre a Rede, nada.

A Internet não entrou ainda no campo do político. O paradoxo é que são as forças de esquerda que na Europa são mais favoráveis à Internet, como se o postulado dos três séculos passados segundo o qual o progresso técnico é a condição do progresso social ainda fosse verdadeiro. Viu-se, no entanto, que foram necessários cento e cinqüenta anos para humanizar o projeto industrial. Com a Internet, faz-se como se fosse a democracia para todos. A direita é em geral bastante mais prudente, ela não propõe o tema da redução da 
abertura como sendo a nova fronteira da democracia. Na realidade, e há muito tempo, a direita é menos fascinada do que a esquerda pela técnica. As estatísticas lhe dão razão: há somente de trezentos a quinhentos milhões de internautas no mundo, dos quais mais de $80 \%$ nos países do Norte, o que é suficiente para relativizar a idéia de revolução "para todos", exceto para acreditar que o aumento do número de computadores sob domínio do Norte é razoável para a humanidade. Por outro lado, há mais de dois bilhões e quinhentos milhões de televisores e mais de três bilhões de aparelhos de rádio que não interessam a ninguém. Vê-se que somente uma poderosa vontade política decidindo integrar a Internet a um projeto mais vasto poderia evitar que o desequilíbrio Norte-Sul se agrave.

Em seguida, é preciso relativizar a "revolução" da Internet. O que é prometido hoje pela Rede já o foi pela primeira explosão da informática há quarenta anos, depois pelo cabo, depois a fibra, depois os satélites. Sempre com o mesmo argumento: se a revolução técnica não teve o efeito esperado sobre a sociedade, é porque as técnicas não eram suficientemente eficientes. Será feito amanhã o que não se pôde fazer ontem!

Relativizar é também, por exemplo, compreender que a sociedade da informação corre o risco de ser amanhã a sociedade do mesmo, porque ela favorece a ligação entre indivíduos e comunidades que se parecem, deixando de lado a questão da heterogeneidade. Conseguir coabitar com aqueles que não se parecem comigo não é um problema técnico, mas uma questão inteiramente política. O que está em jogo hoje é resistir à segmentação da sociedade em pequenas comunidades para preservar esse mínimo de sentimento de coletividade sem o qual não há sociedade.

O individual contra o coletivo, a segmentação contra a sociedade, e mesmo contra o diferente: sobre todos esses problemas essenciais para o futuro de nossas sociedades, a Rede, quando se presta atenção nela, pode aprofundar os aspectos mais conformistas.

Enfim, é preciso sair das performances e voltar aos ideais. Sem os quais a Internet, que deveria tudo mudar, poderia terminar não sendo mais que uma simples disposição harmônica das relações individuais, deixando de lado a questão central da política: a organização pacífica da coabitação no seio de uma mesma sociedade.

Se os internautas convencidos de uma Internet democrática querem conservar uma real iniciativa, é preciso uma aliança entre eles e todas as forças culturais, sociais e políticas que compreenderam que a comunicação é um dos maiores desafios da sociedade de amanhã. Isso obriga a revalorizar uma visão humanista das ligações entre informação e comunicação, trabalho ainda não começado se se julga a desvalorização do conceito "com", seguidamente relacionado ao marketing e à manipulação, enquanto a informação é subvalorizada, como se ela permanecesse o gênero raro que era no século das Luzes. É preciso dissociar o mais rápido possível a informação que permanece fiel a uma certa filosofia democrática daquela que se ergue antes de tudo de uma lógica instrumental e econômica.

Sair das performances e voltar aos ideais, é enfim separar essas três dimensões da informação e da comunicação constantemente misturadas, mas de valores radicalmente diferentes: uma aspiração humana fundamental, um símbolo de liberdade e de emancipação, a matéria-prima de um novo princípio de acumulação econômica e social. Admitir essa ambivalência fundamental, pensá-la e administrá-la para aprender a distinguir qual dessas três referências domina nas diferentes situações. De qualquer forma, é preciso inventar um tipo de véspera democrática da revolução da informação e da comunicação onde se aplicam 
três processos: entendimento entre os atores, uma reflexão e uma ação sobre a regulamentação, enfim, a avaliação e a valorização das experiências interessantes.

O que está em jogo? Sair o mais rápido possível desse vocabulário da sociedade da informação ou a sociedade será absorvida pela técnica. Escapar da ideologia técnica é reencontrar os valores contraditórios, mas essenciais, de toda sociedade e de toda democracia.

Gostaria, enfim, de abrir uma última pista de reflexão: até onde o homem pode viver num universo de signos, quer dizer de imagens, de sons, de dados informáticos, sem contato com a natureza e o mundo físico?

A noção de progresso foi por muito tempo compreendida como a transformação da natureza e da matéria, esses dois "parceiros-adversários" contra os quais os homens lutaram durante séculos. Com a emergência da sociedade industrial, a potência técnica não conheceu mais limites. As usinas, com suas construções e suas chaminés, foram seu símbolo por muito tempo.

Nós mudamos hoje de época: os homens são menos fascinados pela potência industrial da qual eles puderam medir os estragos humanos e ecológicos, e mais atraídos pelas técnicas da informação. Menores, menos poluentes, elas fascinam porque colocam em obra a rapidez, a performance, a interatividade. $E$, desta vez, parece que não há brutalidade no progresso, nem preço a pagar.

Mas qual experiência da realidade sobra quando a atividade econômica, social, cultural, escolar é reduzida à gestão de signos? O homem também tem necessidade de certa relação com a natureza e o mundo físico, como ele tem necessidade de se confrontar com as ligações humanas e com a diversidade das relações sociais na sociedade. Nós vivemos num universo amplamente urbano, onde mais de $70 \%$ da população trabalha nos serviços, sem contato com o mundo físico, e onde os operários, os artesãos e os camponeses tornam-se quase curiosidades... É no que o tema da sociedade da informação é perverso: ele homogeneiza tudo e faz desaparecer o homem por atrás dos fluxos da informação.

Numa economia do signo, tudo é possível. Cabe então ao homem inventar seus próprios limites.

A história ensina que o homem tem sempre uma incalculável capacidade de destruição em si mesmo. Se não se quer que as técnicas mais sofisticadas que o homem inventou sejam a oportunidade para uma nova desumanização, é preciso preservar o homem, suas fraquezas, suas forças e suas contradições. Porque só ele sonha o futuro, pensa sua história e dá sentido a sua experiência .

Nota

Texto publicado originalmente em Internet - petit manuel de survie. Paris, Flammarion, 2000. Cedido pelo autor. Traduzido por Daniela Dariano. 